\title{
Change In Proximate Composition And Microbial Count By Low Temperaturepreservation In Fish Muscle Of Labeo Rohita(Ham- Buch)
}

\author{
Roopma Gandotra , Meenakshi Koul*, Sweta Gupta and Shallini Sharma \\ *Department of Zoology, University of Jammu, Jammu, 180006
}

\begin{abstract}
The study was designed to investigate the effect of low temperature preservation on the chemical and microbial profile of fish muscle (Labeo rohita) stored for a period of twenty one days. The proximate composition and microbiological analyses were carried out at 7 days interval on muscle of fish during frozen storage. It was found that the protein, lipid, moisture and ash contents decreased significantly $(P<0.05)$ during

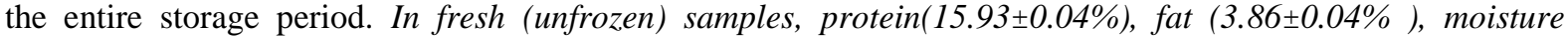
$(84.74 \pm 0.1 \%$.), and ash content $(1.79 \pm 0.01 \%)$ were found to be the highest, where as the total percent decrease in frozen samples on $21^{\text {st }}$ day of frozen storage was (12.99\%), (22.27\%), (4.60\%) and (24.02\%) for protein, fat, moisture and ash respectively. The microbial count increased gradually during the period of storage. The Total Plate Count in fresh fish muscle on day zero was rather low i.e. $2.44 \pm 0.2 \log$ cfu/g as compared to the values found on the $21^{\text {st }}$ day i.e. 5.10 $\pm 0.02 \mathrm{log}$ cfu/g. The Coliform Count also followed the same trend during the storage. On day zero, a few colonies were found and the CC was $1.50 \pm 0.15 \log$ cfu/g where as it increased up to $3.08 \pm 0.07$ log cfu/g on last day of storage. Similarly Psychrophillic count increased from $2.15 \pm 0.2$ log cfu/g on day zero to $5.06 \pm 0.05 \log \mathrm{cfu} / \mathrm{g}$ on $21^{\text {st }}$ day. Thus, a significant quality loss was observed in fish during storage. However, the present frozen conditions retained the fish under acceptable microbial conditions for human consumption up to $14^{\text {th }}$ day beyond which it became unfit for human consumption.
\end{abstract}

Keywords: Frozen period, biochemical, microbial, Labeo rohita

\section{Introduction}

Fish has been playing an important role in addressing nutritional and livelihood security of people in the developing countries. Fish provides $20 \%$ of animal protein intake to about 2.6 billion people globally and at least 50\% of animal protein intake for over 400 million in Asia and Africa. But, in developed countries, it provides only $13 \%$ of animal protein intake (FAO, 2008). Fish is one of the most highly perishable commodities and the public has always required continuous reassurance about its quality. The spoilage process begins immediately after capture. Harmless, natural spoilage bacteria on the skin and in the slime of the fish quickly invade the muscle blocks. However, for the first couple of days, changes in the fish are predominantly due to the intrinsic enzymes in the flesh. Fish is an extremely perishable food and should be handled with great care to inhibit the growth of micro-organisms. The high ambient temperature of our country favours the rapid growth of micro-organisms. With higher ambient temperature, fish quality deteriorates very rapidly and low temperature storage is the method of preservation recommended to retard microbial spoilage of fish (FAO, 1993). The effect of microbial activity on fresh seafood proteins results in a pronounced off flavor and off odour, which can lead to a short shelf life and economic loss. Retail sales of fresh seafood items are expanding and this necessitates developing alternate preservation methods to extend the shelf life of fresh seafood product.

Shelf-life extension can be achieved by various preservation methods, i.e., refrigeration, freezing, salting, brining (wet salting), icing, smoking, glazing, drying, frying etc. Refrigeration and freezing help in preserving fish by lowering temperature. At low temperature, micro-organisms become inactive, enzymatic activity also slows down, thus biochemical activities decreases. Consequently, the fish remain free from spoilage for longer duration.

The freezing of fish is an effective way of long term preservation and it has been shown that fish stored for up to three months under ideal conditions cannot be distinguished from fresh fish regarding color, taste and texture (Cappeln et al., 1999; Nielsen and Jessen, 2007).Freezing and frozen storage of fish muscle may, however, lead to denaturation and aggregation of especially myofibrillar proteins. These changes result in altered functional properties, changed textural attributes and reduced water holding capacity and juiciness. The result is a hard, dry and fibrous fish product with a reduced eating quality. Moreover, liquid losses may also directly result in economic losses (Barroso et al., 1998).

Freezing is currently one of the most widespread methods of conserving fish. During the freezing process and frozen storage, fish muscle can undergo a number of changes, such as denaturation and aggregation of the myofibrillar proteins. This results in alteration of the functional properties of muscle proteins, loss of 
Change in proximate composition and microbial count by low temperature Preservation in fish

water-holding capacity and juiciness and unwanted changes in texture, which produces a hard, dry and fibrous product. This is especially important in some lean species (e.g. gadoids) where greater changes in texture occur than in fatty and semi-fatty fish (Barroso et al., 1998). In addition, lipid oxidation is one of the major causes of deterioration in the quality of fish and fish products during frozen storage (Mackie, 1993; Verma et al., 1995). Oxidative deterioration of lipids can directly affect quality characteristics such as color, flavor, texture, nutritive value and safety (Wang, 2009). Freezing and frozen storage have largely been employed to retain the sensory and nutritional properties of fish although enzymatic and non-enzymatic rancidity is known to develop strongly under such conditions (Harris \& Tall, 1994; Erickson, 1997). During frozen storage, enzymatic and nonenzymatic rancidity is highly influence the shelf life of marine products due to unsaturated lipid composition and the presence of prooxidant molecules in the their muscles (Ackman, 1989; Aubourg et al., 2004). Keeping this in mind, the primary objective of the present work has been designed to generate information on the changes in biochemical and microbiological composition of raw muscle of a fish (Labeo rohita) available in the local market of Jammu, stored in frozen conditions $\left(-12 \pm 2^{0} \mathrm{C}\right)$ so as to determine their quality change during storage period of 21 days. This study has immense importance to satisfy consumer's query relating to and how long fish muscle can be stored without any deterioration in domestic refrigerator for the betterment of the public health.

\section{Materials And Methods}

\section{Sample collection}

Fresh samples of Labeo rohita were purchased from local market of Jammu city. They were immediately brought to the lab in polythene bags along with crushed ice. The viscera of fish were removed and the fish was washed with large amount of water. The fish was cut in to pieces and these pieces immediately wrapped in aluminum foil, kept in air tight plastic container and stored at $12 \pm 2^{\circ} \mathrm{C}$ (frozen storage). Analytical procedures for biochemical and microbiological changes were done on $0,7^{\text {th }}, 14^{\text {th }}$ and $21^{\text {st }}$ day of storage.

\section{Analyses}

The proximate composition (ash and moisture) of the fish samples were evaluated using the standard AOAC procedure (AOAC, 1995). The protein content was determined using the Lowry et al. (1951). Fat content was determined using Folch et al. (1957). The microbiological profile was determined according to APHA method (1984). Data were expressed as mean \pm SD and were analyzed by one-way ANOVA test using SPSS statistical programme.

\section{CHEMICAL ANALYSIS}

III. Results And Discussion

Protein Content. Perusals of (table 1) revealed that the highest protein content $(15.93 \pm 0.04 \%)$ was recorded for fresh (unfrozen) fish samples and the least protein content $(13.06 \pm 0.04 \%$.) was recorded for fish sample stored for 21 days at $-12 \pm 2^{0} \mathrm{C}$. A significant percent decrease $(\mathrm{p} \leq 0.05)$ was found in total protein content i.e. $5.77 \%$, $11.23 \%$ and $18.01 \%$ on $7^{\text {th }}, 14^{\text {th }}$ and $21^{\text {st }}$ day of storage respectively.(table 2).In support of present findings, Bekelvik et al (2005) in sea bass(Dicentrarchus labrex) and Siddique et al. (2011) in Puntius sps reported significant decrease in protein content during frozen storage. They attributed this protein loss due to the leaching affect of amino acids and water soluble protein leaching out with melting ice. According to Xiong (1997), Zamir et al (1998) and Saeed \& Howell (2002) proteins exposed to oxidizing environments are very susceptible to chemical modification, such as amino acid destruction, peptide scission and formation of protein-lipid complexes that results in decrease in protein content.

Table 1. Proximate composition (wet weight basis) of raw fish muscle of (Labeo rohita) stored In freezer at $-12 \pm 2^{\circ} \mathrm{C}$ during 21 days of storage

\begin{tabular}{|l|l|l|l|l|}
\hline DAYS & 0 day & $7^{\text {th }}$ day & $14^{\text {th }}$ day & $21^{\text {st }}$ day \\
\hline $\begin{array}{l}\text { Total Protein } \\
(\%)\end{array}$ & $15.93^{\mathrm{a}} \pm 0.04$ & $15.01^{\mathrm{b}} \pm 0.02$ & $14.14^{\mathrm{c}} \pm 0.03$ & $13.86^{\mathrm{d}} \pm 0.04$ \\
\hline Total Lipid (\%) & $3.86^{\mathrm{a}} \pm 0.04$ & $3.65^{\mathrm{b}} \pm 0.02$ & $3.25^{\mathrm{c}} \pm 0.04$ & $3.00^{\mathrm{d}} \pm 0.03$ \\
\hline Moisture (\%) & $84.74^{\mathrm{a}} \pm 0.1$ & $83.82^{\mathrm{b}} \pm 0.015$ & $82.64^{\mathrm{c}} \pm 0.02$ & $80.84^{\mathrm{d}} \pm 0.09$ \\
\hline Ash (\%) & $1.79^{\mathrm{a}} \pm 0.01$ & $1.69^{\mathrm{b}} \pm 0.012$ & $1.57^{\mathrm{c}} \pm 0.02$ & $1.36^{\mathrm{d}} \pm 0.03$ \\
\hline
\end{tabular}

--Mean \pm SD with different superscripts in a row differs significantly $(\mathrm{P}<0.05)$ 
Table 2.Percental decrease in proximate composition during low temperature

\begin{tabular}{|l|l|l|l|l|}
\hline DAYS & Protein\% & Lipid\% & Moisture\% & Ash\% \\
\hline $0-7$ & 5.77 & 5.44 & 1.08 & 5.58 \\
\hline $0-14$ & 11.23 & 15.80 & 2.47 & 12.29 \\
\hline $0-21$ & 12.99 & 22.27 & 4.60 & 24.02 \\
\hline
\end{tabular}

Preservation from 0 day to $21^{\text {st }}$ day

Lipid Content. The results shown in the table 1 revealed that the lipid content decreased significantly $(\mathrm{p} \leq 0.05)$ from day 0 i.e. $3.86 \pm 0.03 \%$ to $3.00 \pm 0.03 \%$ on $21^{\text {st }}$ day. There was $5.44 \%, 15.80 \%$ and $22.27 \%$ decrease in total lipid content on $7^{\text {th }}, 14^{\text {th }}$ and $21^{\text {st }}$ day respectively during frozen storage of 21 days at $-12 \pm 2{ }^{0} \mathrm{C}$. (Table 2).In favor of present findings Arannilewa et al(2005) in Tilapia;Peter et al (2010) in Alaska Pollack (Theragra chalcogramma) and Siddique et al (2011) in Puntius sps found a significant loss in total lipid content when stored at low temperature. These workers attributed this loss due to oxidation of lipid that is the major cause of deterioration of fish.

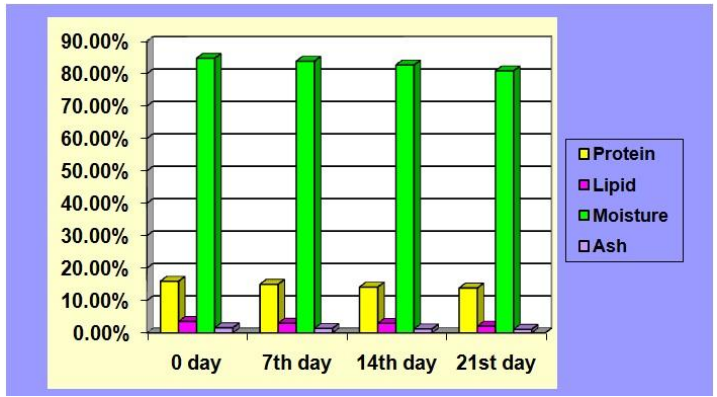

FIGURE 1: Change in Proximate composition (wet weight basis) of (Labeo rohita) subjected to Low temperature preservation in 21 days of storage.

Moisture Contents. Perusals of Table 1 showed that initially on day 0,moisture content was found to be $84.74 \pm 0.1 \%$ and it decreased significantly to the value of $80.84 \pm 0.09 \%$ on $21^{\text {st }}$ of storage at $-12 \pm 2^{0} \mathrm{C}$. The results depicted that there was $1.08 \%, 2.70 \%$ and $4.60 \%$ decrease in moisture content on $7^{\text {th }}, 14^{\text {th }}$ and $21^{\text {st }}$ day respectively. These results are in accordance with Alasalvar et al (2002), Orban et al (2002) and Bekelvik et al (2005) who reported a decrease in total moisture content in sea bass (Dicentrarchus labrax) fillets during frozen storage. This decrease in moisture content was attributed to the sublimation of ice in frozen storage and drip loss during thawing process by them. Kandeepan \& Biswas (2007) reported a decrease of $1.57 \%$ in total moisture content in buffalo meat after seven days of frozen storage. In contrary to the results of present study, Zamir et al (1998) in crab; Bao et al (2007) in Arctic Charr(Salvelinus alpinus) and Siddique et al (2011) in Puntius sps found an increasing trend in moisture content. Zamir et al (1998) attributed this increase to the loss of water holding capacity of tissue.

Ash content Result shown in table 1 revealed that the ash content decreased significantly from $1.79 \pm 0.01 \%$ on day 0 to $1.36 \pm 0.03 \%$ on $21^{\text {st }}$ day of storage at $-12 \pm 2^{0} \mathrm{C}$. There was a total decrease of $5.58 \%, 12.29 \%$ and $24.02 \%$ on $7^{\text {th }}, 14^{\text {th }}$ and $21^{\text {st }}$ day of storage respectively(Table 2). These results are in agreement with Beklevik et al(2005) while working on sea bass fillets;Okoyo et al(2009) on Nile perch and Emire et al(2009) on Tilapia,(Oreochromis niloticus) reported a decrease in total ash content during its frozen storage. But Arannilewa et al (2005) observed that the ash content remained almost the same throughout the 60 days of frozen storage of tilapia. However Khan et al (2005) reported a strong correlation between the storage period and ash content $(\mathrm{r}=0.819, \mathrm{p} \leq 0.0002)$ in blue mussels (Mytilus edulis) during storage in ice. The decrease in ash and moisture content was attributed to the drip loss during thawing process by Beklevik et al (2005).

\section{Microbial Quality}

For the determination of freshness quality of fish before and frozen storage, total plate count (TPC), Coliform count (CC) and Psychrophillic count (PC) were analyzed.

The results presented in (Table 3) depicted that the total plate count (TPC) increased from initial load of $2.04 \pm 0.2 \mathrm{log} \mathrm{cfu} / \mathrm{g}$ to $5.10 \pm 0.2 \mathrm{log} \mathrm{cfu} / \mathrm{g}$ after 21 days of frozen storage. The above results clearly revealed that the microbial growth was more rapid with increasing storage period. It has been found in the present studies that the TPC on $21^{\text {st }}$ day of storage $(5.10 \pm 0.2 \log \mathrm{cfu} / \mathrm{g})$ was within the permissible limit of $6 \log \mathrm{cfu} / \mathrm{g}$ (ICMSF, 
Change in proximate composition and microbial count by low temperature Preservation in fish

1986). Similarly, Bao et al (2007) found faster microbial growth in chilled than in super chilled samples of Arctic Charr under the effect of dry ice. Similar increment on total bacterial load in muscle at low temperature storage was reported by Obemeata et al (2011). They stated that freezing of fish at $-18^{0} \mathrm{C}$ created an unfavorable environmental condition for the growth and the survival of the micro-organisms, while freezing at $4^{0} \mathrm{C}$ allows the rapid proliferation of the micro-organisms. Ozogul et al (2011) also reported a significant statistical increase $(\mathrm{p} \leq 0.05)$ in the Initial total viable counts of whole gutted common sole (Solea solea) over the storage period of 24 days. Lawire (1998) attributed the microbial growth to the growth promoting effect of moisture on microbes in meat stored in chiller and Yohanna et al (2011) to the less acid enzymatic reactions of fish flesh.

Table 3: Change in microbial count of fish muscle of Labeo rohita during low temperature Preservation at $-12^{0} \mathrm{C}$ from 0 day to $21^{\text {st }}$ day

The --

\begin{tabular}{|l|l|l|l|l|}
\hline $\begin{array}{l}\text { Days of } \\
\text { storage }\end{array}$ & $\mathbf{0}$ day & $\mathbf{7}^{\text {th }}$ day & $\mathbf{1 4}^{\text {th }}$ day & $\mathbf{2 1}^{\text {st }}$ day \\
\hline TPC log cfu/g & $2.04^{\mathrm{a}} \pm 0.2$ & $4.01^{\mathrm{b}} \pm 0.11$ & $4.30^{\mathrm{c}} \pm 0.07$ & $5.10^{\mathrm{d}} \pm 0.02$ \\
\hline CC log cfu/g & $1.15^{\mathrm{a}} \pm 0.15$ & $2.0^{\mathrm{b}} \pm 0.2$ & $2.14^{\mathrm{c}} \pm 0.1$ & $3.08^{\mathrm{d}} \pm 0.07$ \\
\hline PC log cfu/g & $2.15^{\mathrm{a}} \pm 0.2$ & $3.30^{\mathrm{b}} \pm 0.04$ & $4.45^{\mathrm{c}} \pm 0.1$ & $5.96^{\mathrm{d}} \pm 0.05$ \\
\hline
\end{tabular}

Mean \pm SD with different superscripts in a row differs significantly $(\mathrm{P}<0.05)$

The Coliform count increased exponentially with the increase in storage time. Perusals of (table 3 ) revealed that in 21 days of storage, it increased from initial value of $1.15 \pm 0.15 \mathrm{log} \mathrm{cfu} / \mathrm{g}$ to final value of $3.08 \pm 0.07 \log \mathrm{cfu} / \mathrm{g}$, thus crossed the permissible limit i.e. $2.69 \mathrm{log} \mathrm{cfu} / \mathrm{g}$ recommended by Goldenberg and Elliot(1973) after $14^{\text {th }}$ day of storage. Kandeepan \& Biswas (2007) also found this pattern of growth in refrigeration and frozen storage of buffalo meat. Similar trends have been registered by several workers namely, Arannilewa et al. (2005), Uzeh et al. (2006), Kumolu-Johnson et al. (2010) and Bhat et al. (2010).

The changes in microbial flora of fish muscle samples during frozen storage are presented in Fig.3

Figure 3. Changes in Total Plate Count (TPC), Coliform count (CC) \& Psychrophillic count (PC) of fish muscle stored at $-12 \pm 2^{0} \mathrm{c}$ for up to 21 days.



The Psychrophillic count was also found to be increase from $2.15 \pm 0.2 \log$ cfu/g on day 0 to $5.96 \pm 0.05$ $\log \mathrm{cfu} / \mathrm{g}$ on final day of storage as shown in (Table 3),thus crossing the permissible limit i.e. $4.6 \mathrm{log} \mathrm{cfu} / \mathrm{g}$ on $14^{\text {th }}$ day as proposed by Cremer \& Chepley (1977). During ice storage of Croaker (Pseudotholitus senegalensis), Ola \& Oladipo (2004) found that psychrophiles increased in number and accounted for over $90 \%$ of the spoilage flora when fish were considered spoiled. The spoilage during iced storage is caused by psychrophiles irrespective of the original bacterial flora according to their findings. Liu (2010) investigated that Psychrophillic bacteria grew exponentially from initial load of $3-4 \log \mathrm{cfu} / \mathrm{g}$, reaching $7.4 \log \mathrm{cfu} / \mathrm{g}$ on day 13 and up to about $9.0 \log \mathrm{cfu} / \mathrm{g}$ in tilapia fillets at the end of storage.

\section{References}

[1]. Ackman, R. (1989). Fatty acids. In: Marine Biogenic Lipids, Fats and Oils (edited by R.Ackman). CRC Press, Boca Raton: CRC Press., 103-137

[2]. Alasalvar, C., Taylor, K.D.A., Zubcov, E., Shahidi, F., Alexis, M(2002).Differentiation of cultured and wild sea bass (Dicentrarchus labrax): Total lipid content, fatty acid and trace mineral composition. Food Chem, 79: 145-150

[3]. AOAC (1995). Official Methods of Analysis. 16th Edn.. Association of Official Analytical Chemists, Washington, DC., USA

[4]. APHA (1984). Compendium of method of microbiological examination of foods. 2nd Edn., American Public Health Association, Washington DC Arannilewa, S.T., Salawu, S.O., Sorungbe, A.A. and Ola-Salawu, B.B. (2005). Effect of frozen period on the chemical, microbiological and sensory quality of frozen, tilapia fish (Sarotherodun galiaenus). African Journal of Biotechnology, 4 (8): 852-855.

[5]. Aubourg, S.P., Pérez-Alonso, F. \& Gallardo, J.M. (2004). Studies on rancidity inhibition in frozen horse mackerel (Trachurus trachurus) by citric and ascorbic acids. European Journal of Lipid Science and Technology, 106, 232-240.

[6]. Bao, H. N. D., Arason, S. and Iorarinsdottir, K.A. (2007). Effects of Dry Ice and Superchilling on Quality and Shelf Life of Arctic Charr (Salvelinus alpinus) Fillets; International Journal of Food Engineering: 3(3)/7: 1-27. 
Change in proximate composition and microbial count by low temperature Preservation in fish

[7]. $\quad$ Barroso, M., Careche, M., and Borderias, A.J. (1998). Trends in Food Science \& Technology, 9(6): 223-229.

[8]. Benjakul, S., Visessanguan, W., Thongkaew, C. and Tanaka, M. (2005) Effect of frozen storage on chemical and gel forming properties of fish commonly used for surimi production in Thailand. Food hydrocolloids, 19:197-207

[9]. Bhat, Z.F., Pathak, V., Bukhari S.A.A., Ahmad S.R. and Bhat, H. (2010). Quality changes in Chevon Harrisa (Meat based product) during refrigerated storage. Intr. J. Meat Sci.

[10]. Cappeln, G., Nielsen, J., and Jessen, F. (1999). Journal of the Science of Food and Agriculture, 79(8): 1099-1104.

[11]. Cremer, M.L. and Chipley, J.R. (1977). Satellite food service system: Time and temperature and microbiological and sensory quality of precooked frozen hamburger patties. J. Food Protect., 40: 603-607.

[12]. Erickson, M. (1997). Lipid oxidation: flavor and nutritional quality deterioration in frozen foods. In: Quality in Frozen Food (edited by M.Erickson \& Y.-C.Hung).. 141-173. New York: Chapman and Hall. Folch, J., Less, M. and Sloane, G.W.S. (1957). A Simple Method For The Isolation And Purification Of Total Lipids From Animal Tissues. J. Biol. Chem. 226, 497-509.

[13]. FAO (1993). Fishery Statistics. Aquaculture production .In food and agriculture organization of the united nations.p.213.rome italy

[14]. FAO (2008). Fisheries and Aquaculture Report. No. 889. Cairo, FAO 61p.

[15]. Folch, J., Less, M. and Sloane, G.W.S. (1957). A Simple Method For The Isolation And Purification Of Total Lipids From Animal Tissues. J. Biol. Chem. 226, 497-509.

[16]. Goldenberg, N. and Elliot, D.W. (1973). The value of agreed non-legal specification (In: The microbiological safety of food. Hobbs B.C. and J.H.B. Christian, Eds. Academic Press New York: 363.

[17]. Harris, P. \& Tall, J. (1994). Rancidity in fish. In: Rancidity in Foods (edited by J.Allen \& R.Hamilton). Pp. 256-272. London: Chapman \& Hall.

[18]. International Commission on Microbiological Specifications for Foods (ICMSF), (1986). Sampling plans for fish and shellfish, In: Microorganisms in Foods. Sampling for Microbiological Analysis: Principles and Scientific Applications, 2(2) University of Toronto Press, Toronto, Canada: 181-196.

[19]. Kandeepan, G. and Biswas S., (2007). Effect of low temperature preservation on quality and shelf life of buffalo meat. Am. J. Food Technol., 2: 126-135.

[20]. Khan, M.A., Parrish, C.C. and Shahidi, F. (2005). Quality indicators of cultured Newfoundland blue mussels (Mytilus edulis) during storage on ice: Microbial growth, $\mathrm{pH}$, lipid oxidation, chemical composition characteristics, and microbial fatty acid contents. J. Agric. Food Chem., 53: 7067-7073

[21]. Kirschnik, P.G., Viegas, E. M. M. and Valenti, W.C. (2006). Shelf-Life of Tail Meat of the Giant River Prawn, Macrobrachium rosenbergii, Stored on Ice Journal of Aquatic Food Product Technology, 15(2).

[22]. Kolodzicjska, I., Sikorski, Z.E. and Sandowska, M. (1987).Texture of Cooked Mantle of Squid Illexargentius as Influenced by Specimen Characteristics and Treatments. J. Food Sci. 52(4): 932-935.

[23]. Kumolu-Johnson, C. A., Aladetohun, N. F. and Ndimele, P. E. (2010). The effects of smoking on the nutritional qualities and shelflife of Clarias gariepinus (BURCHELL 1822). African Journal of Biotechnology. 9(1): 73-76.

[24]. Lawrie, R.A. (1998). The storage and preservationof meat II. Moisture control. In:Lawrie's Meat Science, $6^{\text {th }}$ Edn.:191-194.

[25]. Liu, S., Fan, W., Zhong, S., Ma, C., Li, P., Zhou, K., Peng, Z. and Zhu, M., (2010). Quality evaluation of tray-packed tilapia fillets stored at $0^{\circ} \mathrm{C}$ based on sensory, microbiological, biochemical and physical attributes. African Journal of Biotechnology; 9(5), 692701.

[26]. Lowry, O.H., Rosenbrough, N.J., Farr, A.L. and Randall, R.J. (1951). Protein measurement with the folin phenol reagent. J. Biol. Chem., 193: 265-275.

[27]. Mackie, I. M. (1993). The effects of freezing on flesh proteins. Food Reviews International, 9(4), 575-610.

[28]. Nielsen, J. and Jessen, F. 2007. Quality of Frozen Fish. In: Handbook of Meat, Poultry and Seafood Quality. Nollet, L. M. L. (Ed.) Blackwell Publishing, Iowa:577-586.

[29]. Obemeata, O., Nnenna, F.P. and Christopher, N. (2011) Mobiological assessment of stored Tilapia guineesis. Afric. J.Food Sci. 5(4):242-247

[30]. Okeyo, G.O., Lokuruka, M.N.I. and Matofari, J.W. (2009). Nutritional composition and shelflife of the Lake Victoria Nile Perch (Lates Niloticus) stored in ice. African Journal of Food Agriculture and Nutrition and Development, 9(3): 901-919.

[31]. Ola, Joseph Babajide and Oladipo, Adnes Etanuoma. (2004) Storage life of Croaker (Pseudotholitus senegalensis) in ice and ambient temperature. African Journal of Biomedical Research, 7: 13-17.

[32]. Orban, E., Di Lena, G., Nevigato, T., Casini, I., Santaroni, G.,Marzetti, A., Caproni, R.(2002).Quality characteristics of sea bass intensively reared and from lagoon as affected by growth conditions and the aquatic environment. J. Food Sci., 67:542-546

[33]. Ozogul, Y., Boga, E. B.,Tokur, B. and Ozogul, F. (2011). Changes in biochemical, sensory and microbiological quality indices of common Sole (Solea solea) from the Mediterranean Sea during ice storage. Turkish Journal of Fisheries and Aquatic Science. 11:243-251

[34]. Saeed, S. and Howell, N.K. (2002). Effect of lipid oxidation and frozen storage on Muscle of Atlantic Mackerel (Scomber scombrus). J. Sci. Food Agric., 82: 579-586.

[35]. Siddique, M.N., Hasan,M.J., Reza, M.Z., Islam,M.R., Boduruzaman M., Forhadur, M. and Reza, S. (2011). Effect of freezing time on nutritional value of Jatpunti (Puntius sophore), Sarpunti ( $P$. sarana) and Thaisarpunti ( $P$. gonionotus). Bangladesh Research Publications Journal 5(4): 387-392.

[36]. Uzeh, R. E. Ohenhen, R. E. and Adeniji, O. O. (2006). Bacterial Contamination of Tsire-Suya, a Nigerian Meat Product. Pakistan Journal of Nutrition; 5 (5): 458-460.

[37]. Verma, J.K., Srikar, L.N., Sudhakara, N.S. \& Sarma, J. (1995). Effects of frozen storage in lipid freshness parameters and some functional properties of oil sardine (Sardinella longiceps) mince. Food Research International, 28, 87-90

[38]. Wang, T. (2009). Oxidative deterioration of lipids can directly affect quality characteristics such as colour, flavour, texture, nutritive value and safety. $\mathrm{PhD}$ thesis, Faculty of food science and nutrition school of health sciences, University of Iceland, Island. 5

[39]. Xiong, Y. L. (1997). Protein denaturation and functionality losses. In M. C. Erickson, \& Y. C. Huang (Eds.), Quality in frozen food New York: Chapman \& Hall: 111-140

[40]. Zamir, M., Qasim, R., and Ullah, A. (1998). Changes in physical and chemical constituents of crab meat during storage at refrigerator temperature $\left(7 \pm 2^{\circ} \mathrm{C}\right)$. Pak. J. of Pharma. Sci. 11(1): 27-33, 